\title{
New Approaches in X-ray Phase Analysis of Gypsum Raw Material of Diverse Genesis
}

\author{
V. Klimenko ${ }^{(\bowtie)}$, V. Pavlenko, and T. Klimenko \\ Belgorod State Technological University named after V G Shukhov, \\ Belgorod, Russia \\ klimenko3497@yandex.ru
}

\begin{abstract}
Modern software was used to conduct X-ray phase analysis of gypsum raw material of different genesis: gypsum from several deposits, citrogypsum, phosphogypsum, vitamin gypsum, chemically pure gypsum, hydration products from different gypsum and anhydrite cementing and composite materials on their bases. Two criteria for ranging gypsum raw material with the account of genesis and structural characteristics and predicting properties of gypsum bindings and materials based on them were suggested: structure sophistication criteria $\left(\mathrm{K}_{\mathrm{g}}\right)$ and identity criteria $\left(\mathrm{K}_{\mathrm{i}}\right)$. They were calculated by the results of X-ray phase analysis of calcium sulphate.
\end{abstract}

Keywords: Gypsum $\cdot$ X-ray phase analysis $\cdot$ Structure sophistication criteria $\cdot$ Identity criteria $\cdot$ Gypsum texture and structure

\section{Introduction}

There are convincing theoretical and experimental data about physical-chemical processes of gypsum dehydration, their structural defects dominating role, an origin and transformation mechanism of these defects during calcinations, at the same time there are no data about influence of the gypsum raw material formation on these processes. Thermodynamic characteristics of gypsum with different structure are rather close (Kelly et al. 1948; Reference... 2004) and it is difficult to study gypsum raw material deformations according to them. There are data (Gordashevski 1963) about application of differential thermal and x-ray analysis methods for these purposes. To characterize gypsum from different deposits P.F. Gordashevskiy (Gordashevski and Sakhno 1963) suggested identity criteria - the value received by division of reflexes intensivities difference at $2 \Theta=20^{\circ}$ and $23^{\circ}$ by their sum. On the other hand, gypsum crystal lattice defects can be characterized by crystallinity degree, which is determined by reflex with $\mathrm{d}=2.81 \AA$ in the X-ray patterns (Boldyrev 1983). Crystallinity degree diagnostics is possible in relation to diffraction reflection doublet intensivity and by crystallinity index determination. Some authors suggest studying crystal lattice defects by studying X-ray diffraction line broadening (Ginje 1961). Literature analysis shows wide researches in this sphere as well as absence of practical standards. In connection with this the purpose of this work was to find new criteria allowing ranging gypsum raw material with the account of genesis and structural characteristics at designing composite materials. 


\section{Materials and Methods}

As raw materials we studied gypsum of Shedok, Baskunchak, Novomoskovsk, and Peshelansk Deposits; man-induced gypsum - chemically pure gypsum, citrogypsum, vitamin gypsum, Voskresensk phosphogypsum, synthetical gypsum; gypsum thermal treatment and rehydration products, composite materials based on gypsum binders, multiphase gypsum binders (MGB). To receive composite materials, we used crashed glass withdrawals (CGW) and iron-ore concentrate of Lebedinsk mining and processing enterprise (OMC). X-ray phase analysis of the studied species was done with X-ray diffraction meter DRON-4 by powder pattern method. Grain-size analysis of powdery material was done by laser granulometry method with a MicroSizer 201 installation.

\section{Results and Discussions}

The X-ray phase analysis of the initial raw material showed that intensity and area of the main reflexes depend on its genesis. Intensity (L) and reflex area (S) at interplanar spacing (d) 7,628 $\AA$ are strongly dependent on gypsum raw material. Gypsum raw material genesis influences somewhat lower the intensity and reflex area at $d=4.291$ and 3.069 $\AA$. Reflex intensity at $\mathrm{d}=3.809 \AA$ almost independent of the gypsum raw material nature. The received data evidence that the studied gypsum samples have equal crystal lattice dimensions.

To determine the gypsum raw material genesis influence on its structure and crystal lattice defects several studies of the initial gypsum raw material crystallinity degree and its products of the heat processing have been studied. Here indexes were suggested calculated by reflex area difference division by their sum. The calculations were done for reflexes with the most intensity such as: $7.628 \AA ; 4.291 \AA ; 3.809 \AA ; 3.069 \AA ; 2.880$ $\AA ; 2.687 \AA$.

We found that most indexes slightly depended on raw material genesis. Certain dependencies were observed in changes of two indexes chosen for further work. The first index was structure sophistication index $\left(\mathrm{K}_{\mathrm{g}}\right)$, and the second was identity index $\left(\mathrm{K}_{\mathrm{i}}\right) . \mathrm{K}_{\mathrm{g}}$, was determined by $\mathrm{X}$-ray phase analysis results, as ratio of reflex area difference division at $2 \Theta=29.09^{\circ}(\mathrm{d}=3.069 \AA)$ and $2 \Theta=31.08^{\circ}(\mathrm{d}=2.876 \AA)$ by their sum, a $K_{i}$ as a ration of reflex area difference division at $2 \Theta=20.68^{\circ}(d=4.291$ $\AA)$ and $2 \Theta=31.08^{\circ}(\mathrm{d}=2.876 \AA)$ by their sum.

$$
K g=\frac{S_{29.09}-S_{31.08}}{S_{29.09}+S_{31.08}} \quad K_{i}=\frac{S_{20.68}-S_{31.08}}{S_{20.68}+S_{31.08}}
$$

For natural gypsum $K_{\mathrm{g}}=0.42-0.46$, and for production induced gypsum was $0.560-0.903$ (Table 1). The greater the value $K_{\mathrm{g}}$, the more sophisticated crystal structure was and gypsum raw material was less stable.

We think that $K_{\mathrm{i}}$ value depends on gypsum raw material micro-assembly dimensions. Powdery-material grain-size composition determined by laser granulometry analysis proves a finely crystalline structure of phosphogypsum and citrogypsum. 
Table 1. X-ray phase analysis of gypsum of different genesis

\begin{tabular}{|c|c|c|c|}
\hline \multirow[t]{2}{*}{ № } & \multirow[t]{2}{*}{ Gypsum genesis } & \multicolumn{2}{|c|}{ Index value } \\
\hline & & $\mathrm{Ki}$ & $\mathrm{Kg}$ \\
\hline 1 & Chemically pure gypsum & 0.612 & 0.660 \\
\hline 2 & Shedok deposit gypsum & 0.362 & 0.440 \\
\hline 3 & Baskunchak deposit gypsum & 0.448 & 0.420 \\
\hline 4 & Novomoskovsk deposit gypsum & 0.448 & 0.450 \\
\hline 5 & Peshelansk deposit gypsum & 0.215 & 0.450 \\
\hline 6 & Vitamin gypsum & 0.746 & 0.903 \\
\hline 7 & Voscresensk phosphogypsum & 0.404 & 0.560 \\
\hline 8 & Citrogypsum 1 & 0.312 & 0.640 \\
\hline 9 & $\mathrm{CaCl}_{2}$ and $\left(\mathrm{NH}_{4}\right)_{2} \mathrm{SO}_{4}$ gypsum & - & 0.749 \\
\hline 10 & Anhydrite cement $\left(1,5 \%\left(\mathrm{NH}_{4}\right)_{2} \mathrm{SO}_{4}+0,5 \% \mathrm{CuSO}_{4}\right)$ & 0.277 & 0.169 \\
\hline 11 & $\begin{array}{l}\text { Composite material based on MGB and CGW remains (Klimenko } \\
\text { et al. 2013) }\end{array}$ & 0.286 & 0.156 \\
\hline 12 & $\begin{array}{l}\text { Composite material: } 70 \% \mathrm{CuSO}_{4} \mathrm{II}+30 \% \mathrm{LC} \\
70 \% \Gamma-4+30 \% \text { LC (Klimenko et al. 2018) }\end{array}$ & $\begin{array}{l}0.370 \\
0.270\end{array}$ & - \\
\hline
\end{tabular}

Crystal size of production induced chemically pure gypsum and vitamin gypsum is higher. They can be referred to large grained gypsum. By value $\mathrm{K}_{\mathrm{i}}$ Shedok natural gypsum can be referred to finely crystalline raw material (finely tessellated oriented structure). Baskunchak natural gypsum has medium tessellated chaotic structure, and according to value $\mathrm{K}_{\mathrm{i}}$ it takes intermediate position.

Hence, for large grained gypsum $K_{i}=0.612-0.746$, for finely crystalline gypsum $\mathrm{K}_{\mathrm{i}}=0.312-0.488$. Granulometry of produced gypsum changes unevenly. There are fractions, which number depends greater on genesis, and there are fractions, which number depends less on raw material genesis. To analyze the influence of gypsum heat treatment parameters and amount of residue hydrate water on value $K_{g}$ and $K_{i}$ we used Baskunchak natural gypsum. The results show that $K_{g}$ of calcium sulphate hydration products can be both greater and less $\mathrm{K}_{\mathrm{g}}$ of natural gypsum. Gypsum produced during heat treatment products hydration with hydrate water 11.00-14.42 mass\%, has sophistication structure index value greater than that of natural gypsum. The smallest value $\mathrm{Kg}$, irrespective of heat treatment parameters is of calcium sulphate hydration products with hydrate water amount 3-4 mass $\%$. Calcium sulphate hydration products having value $K_{\mathrm{g}}$ close to $\mathrm{K}_{\mathrm{g}}$ of the initial gypsum, have maximum strength. The amount of residue hydrate water of these products is equal 1.0-1.5 mas. \% . By value $\mathrm{K}_{\mathrm{i}}(0.39$ $0.45)$ the produced gypsum can be classified as fine- or medium crystalline structure.

Analysis of identity index value suggests that calcium sulphate hydration products with the amount of hydration water 10-15 mass $\%$ have bigger crystal micro cluster size and hydration products $\beta-\mathrm{CaSO}_{4} \cdot 0.5 \mathrm{H}_{2} \mathrm{O}$. $\beta$-centrifuged hemihydrates of calcium sulphate and soluble anhydrous plaster $\left(\beta-\mathrm{CaSO}_{4} \cdot \mathrm{III}\right)$ have smaller size of gypsum crystal micro clusters $\left(K_{i}=0.35-0.43\right)$. 


\section{Conclusion}

A method and parameters (structure sophistication index $\left(K_{\mathrm{g}}\right)$ have been suggested and identity index $\left(\mathrm{K}_{\mathrm{i}}\right)$ ) allowing ranging gypsum raw material with the account of genesis and structural characteristics and forecast properties of gypsum cementing components and materials on their basis. It has been determined that for natural gypsum $\mathrm{K}_{\mathrm{g}}=0.42-$ 0.46 and for produced gypsum $K_{\mathrm{g}}=0.560-0.903$. Value $\mathrm{K}_{\mathrm{i}}$ depends on micro clusters sizes of gypsum raw material structure. For large grained gypsum $K_{i}=0.612-0.746$. for finely crystalline gypsums $-0.312-0.488$. At producing gypsum cementing agents it is necessary to observe that their $K_{g}$ is closer to value $K_{g}$ of natural gypsum and $K_{i}$ is in the range $0.38-0.41$.

Acknowledgements. The work is realized within the framework of the Program of flagship university development on the base of the Belgorod State Technological University named after V.G. Shukhov. using equipment of High Technology Center at BSTU named after V.G. Shukhov.

\section{References}

Boldyrev VV (1983) Experimental methods in mechanochemistry of solid inorganic matters. Science, Novosibirsk, $36 \mathrm{p}$

Ginje A (1961) Crystal X-ray filming. State Publishing House of Physic-Mathematical Literature, Moscow, $188 \mathrm{p}$

Gordashevskiy PF, Sakhno ZA (1963) About some properties of gypsum raw material of different crystalline structure, no 26. Collection of works/SRILCM, Moscow, pp 25-27

Gordashevskiy PF (1963) Thermal and X-ray phase gypsum analyses results. Constr Mater (12):28-30

Kelly N, Suttard D, Anderson K (1948) Thermodynamic properties of gypsum. BTI MCMPI, Moscow, pp 38-42

Klimenko VG, Kashin GA, Prikaznova TA (2018) Plaster-based magnetite composite materials in construction. In: IOP Conference Series: Materials Science and Engineering, vol 327, p 032029. https://doi.org/10.1088/1757-899x/327/3/032029

Klimenko VG, Pavlenko VI, Gasanov SK (2013) The role of $\mathrm{pH}$ medium in forming binding substauces on base of calcium sulphate. Middle-East J Sci Res 17(8):1169-1175

Reference book. Gypsum materials and articles (production and application) (2004) Under general editorship of professor, doctor of sciences A.V. Ferronskaya. Construction Universities Association Publishing House, Moscow, 485 p 
Open Access This chapter is licensed under the terms of the Creative Commons Attribution 4.0 International License (http://creativecommons.org/licenses/by/4.0/), which permits use, sharing, adaptation, distribution and reproduction in any medium or format, as long as you give appropriate credit to the original author(s) and the source, provide a link to the Creative Commons license and indicate if changes were made.

The images or other third party material in this chapter are included in the chapter's Creative Commons license, unless indicated otherwise in a credit line to the material. If material is not included in the chapter's Creative Commons license and your intended use is not permitted by statutory regulation or exceeds the permitted use, you will need to obtain permission directly from the copyright holder.

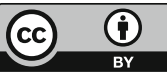

